\title{
BOŠNJAČKI VELIKANI: \\ HUSEIN-BEG KAPETAN GRADAŠČEVIĆ (ZMAJ OD BOSNE) KROZ HISTORIJSKI KALEIDOSKOP DRAMSKOG STVARALAŠTVA NEDŽADA IBRIŠIMOVIĆA, NIJAZA ALISPAHIĆA I FUADA TABAKA
}

\section{Sažetak}

Ciljevi i zadaci ovog rada manifestiraju se u težnji da se na osnovu analiziranih dramskih tekstova, doprinese tvrdnji da embrion historijske dramaturgije treba tražiti u društvenoj potrebi za političkim teatrom pomoću kojega je putem prošlosti kroz poruke univerzalne vrijednosti demistificirana problematika savremenosti. Dakle, drame koje svoje inspiracijsko polazište imaju u prošlosti, koriste prošlost samo kao pogodno tlo za aktualizaciju nekih savremenih problema, te na taj način progovaraju o univerzalnom. Kako bosanskohercegovačka drama uopće nije dovoljno istražena, nije ni čudo koliko se malo pisalo o bosanskohercegovačkoj historijskoj drami koja je jedno vrijeme čak bila $i$ dominanta orijentacija dramskih stvaralaca. U sklopu historijskih dramskih tekstova, posebno se izdvajaju oni koji su inspirirani ličnostima bošnjačkih velikana kao što su Husein-beg Gradaščević, Mehmedpaša Sokolović, Mula Mustafa Bašeskija, muftija Karabeg, Abdulvehab Ilhamija Žepčevi, Alija Đerzelez i mnogi drugi.

Ključne riječi: historijski dramski tekstovi, historija, historija mentaliteta, političko pozorište, Pokret za autonomiju Bosne, kapetanije, simbioza prošlosti $i$ sadašnjosti, demitomanizacija, Husein-beg Gradaščević, Zmaj od Bosne, Nedžad Ibrišimović, Nijaz Alispahić, Fuad Tabak.

\section{Uvod (Zmaj od Bosne ili kapetan Husein-beg Gradaščević)}

Da bi se u potpunosti percipirala dramska prikazanja o Gradaščeviću, neophodno je prije same percepcije dramskog djela proučiti lik i djelo ovog bosanskog junaka, te na taj način percipirane

\footnotetext{
${ }^{1}$ Islamski pedagoški fakultet u Bihaću
} 
dramske dijelove uvlačiti u logički metatekst kroz simbiozu prošlosti (vremena prošlog) i sadašnjosti (vremena sadašnjeg). Zmaj od Bosne, hvalospjevna sintagma koju mu je dao bosanski narod, označava čovjeka po imenu Husein, rođenog 1802. godine u staroj kapetanskoj porodici Gradaščević, od oca Osmana i majke Đurđijanke po imenu Melekhana, koji je igrom slučaja, nakon smrti svoga brata (Muratkapetana, kojeg je pogubio Dželal-paša), naslijedio jednu od najjačih i najznačajnijih kapetanija u Bosni.

$\mathrm{Na}$ osnovu različitih prijepisa iz vremena Osmanskog carstva (Hatt-i Hümayüna-carskih naredbi), te napisa Alekse Ivića o boravku Husein-bega Gradaščevića u Osijeku od 5. jula do 4. oktobra 1832., u svojoj knjizi Pokret za autonomiju Bosne, Aličić Ahmed nam daje gotovo dirljiv opis Husein-bega Gradaščevića, koji predstavlja nešto više od puke historijske biografije nacionalnog junaka. Husein-beg je odgajan kao plemić, kao neko ko će u budućnosti obavljati značajne državne funkcije, te mu je s toga otac obezbijedio privatne učitelje $\mathrm{i}$ vaspitače, od kojih je bio najpoznatiji sarajevski učenjak Mulla Mestvica, a također su ga podučavala i dva šejha, što je svakako uticalo na izgradnju Huseinove pjesničke ličnosti i formiranje Huseina kao velikog vjernika koji je u potpunosti, ali ne fanatično poštovao islamske propise.

Njegov najstariji brat Osman je napredovao do novoga paše i bio je veoma cijenjen $u$ vojnoj hijerarhiji Osmanskog carstva, te je $u$ vrijeme "Pokreta" imao velike probleme zbog svoga brata. Nakon što Husein postaje kapetan, uskoro se proslavlja, kao najuticajniji i najmoćniji čovjek u cijeloj Bosni, a pri tome ne smijemo izgubiti iz vida da njegova kapetanija u tom trenutku slabljenja moći Osmanskog carstva zauzima jedno od strateški najvažnijih položaja, jer graniči i prema Srbiji i prema Austriji. U tom smislu je i zasnovan dramski sukob, na relaciji Austro-Ugarska - Srbija - Osmansko carstvo, koji dirigira političku situaciju u Bosni.

U biografiji Zmaja od Bosne, nužno je spomenuti i fra. Iliju Starčevića, koji je također jedan od omiljenih likova u dramatizaciji prošlosti Bosne, te sačuvane dokumente koji svjedoče da je Husein svojevoljno dao dopuštenje Starčeviću da se sagrade samostan i katolička crkva u Tolisi. Međutim, bez obzira na prevaziđeni pozitivistički biografski pristup nekom književnom djelu, neosporna je 
činjenica da je pri analizi i ove i ostalih drama koje su posvećene Zmaju od Bosne, nužno, ali i zanimljivo povući paralele između stvarnosti i fikcije, a sve s ciljem da olakšamo percepciju univerzalne umjetničke problematike koju nam nameću tri historijske drame nastale inspirirane vremenom prve polovine 19. st. i svim onim događajima na uzavreloj političkoj sceni koji su od Huseina-kapetana gradačačkog stvorili mitskog Zmaja od Bosne.

\section{Nedžad Ibrišimović, Zmaj od Bosne ili historijska faktografija u funkciji otkrivanja psihološke strane historije; historije mentaliteta}

Dramski opus Nedžada Ibrišimovića uglavnom je omeđen i determiniran historijskom inspiracijom koja svoje izvore crpi iz bošnjačke sredine, ali je značajno pomenuti i to da su to teme koje je on uglavnom već zahvatio i obradio u svom opsežnom romanesknom i pripovjedačkim radu. Njegova koncepcija prošlosti je takva da on uvijek teži da u egzistencijalnim odbljescima varijabilne prošlosti pronađe ono što je univerzalno, ono što kao neizlječiva kletva određuje cjelokupno čovječanstvo od njegova postanja, pa tako u starom traži novo, poznato želi učiniti spoznatim, u pojedinačnom traži općeljudsko.

Historija kod Ibrišimovića nije definirana kroz tradicionalnu definiciju koja svoju polaznu tačku uvijek utemeljuje na nekom značajnom historijskom događaju ili na nekoj značajnoj historijskoj ličnost, pa je zbog toga osuđena da ima retrospektivnu tačku gledišta. Nasuprot tome, Ibrišimović historiju definira onako kako je to započeo Niče, a kasnije su mnogi prihvatili tu definiciju historije kao zbira historije mentaliteta, pri čemu se ona nužno mora sagledavati kao stvaralačko tkivo sadašnjosti i budućnosti i upravo zbog toga je najbitnije spoznati ovu psihološku stranu historije. Ovakav koncept vremena Ibrišimović prenosi i na svoje dramske tekstove. U sklopu svog historijskog dramskog opusa, Ibrišimović je obradio i lik čuvenog Huseina-kapetana Gradaščevića. Ova osebujna ličnost predstavlja neiscrpnu inspiraciju za većinu bošnjačkih umjetnika i nije nikakvo čudo, da je ona posebno aktualna u oblasti dramskog stvaralaštva, jer kako je to izjavio sam Nedžad Ibrišimović da je kod "Zmaja od Bosne" samo naslov dramatičan i da je s toga teško 
ostvariti čvrstu dramsku priču, pa je pisati dramsko djelo o ovom veličanstvenom čovjeku pravi istraživački izazov kojem ni Ibrišimović, kao odličan poznavalac bosanske prošlosti, nije odolio.

Kao vrijeme radnje Ibrišimović uzima konkretni historijski okvir, tridesete godine XIX vijeka, te prikazuje tragičnu sudbinu Husein-bega Gradaščevića, kao čovjeka koji je razapet između životnih kontradiktornosti u koje biva uvučen kao tragična žrtva političkih igara koje oduvijek opkoljavaju Bosnu. Husein je rastrgan između želja i mogućnosti, između moći i nužnosti pokoravanja višim silama, između nužnosti poltronstva vlasti i bezgranične slobode. Ibrišimović na vješt način, kreirajući lik koji živi svojevrsnu antonimiju surovih balkanskih prilika u prvim decenijama 19. st. uspijeva problematizirati univerzalne teme o ljudskoj krivici, moralnoj ispravnosti njegovih odluka i postupaka u kriznim trenucima historije (života), dihotomija čistih i prljavih ruku, o smislu ljudskog života u tamnom vilajetu. Ova drama nije inspirirana samo historijom, već i postojećim dramama Zmaj od Bosne, Hamida Šahinovića Ekrema i Ahmeda Muradbegovića. Ova je drama pokazala da historijska događanja mogu maštovitom dramatičaru da posluže za stvaranje jedne nove vizije vremena prošlog $i$ vremena sadašnjeg $u$ smislu premošćivanja vremena, kada se historijom problematizira sadašnjost. Ako posmatramo Šahinovićevog Zmaja od Bosne, možemo zaključiti da on njegov lik i vrijeme posmatra iz vizure svoga vremena (Austro-Ugarska okupacija) i za njega je Husein-beg prvenstveno borac protiv svih tlačitelja slobode, te na osnovu idealiziranja lika Husenin-bega stvara sliku bosanskoga begovata. Sa druge strane, Muradbegović je tragičnu sudbinu Husein-bega sagledao kroz okvire porodično-intimnog odnosa, kroz borbu Husein-bega (probošnjački orijentiranog) sa bratom Osmanom (proosmanlijski orijentiranim), i izgubljenost njihove majke Đule.

Ibrišimović je potpuno izmijenio i strukturu i temu i likove, on je odbacio tendencioznosti i "državotvornosti" te pobunu glavnog lika problematizirao filozofski, kao odnos pojedinca i vlasti, slobode i neslobode, prava da se misli drugačije nego što misle silnici, ali i nemoć da se san o slobodi ostvari, sem u vlastitoj smrti, ili, ono najstrašnije, u izdaji samoga sebe, ulizivanju vlasti, pokajničkom priznanju svojih zabluda i molbi za oprost i milost. Ibrišimović koristi postupak oneobičavanja i udaljuje se od historijske faktografije 
(posavski fratri). Tako je on iskomponirao i sliku vlasti, zamislivši da sve silnike, od Ali Dželaludina do Sultana tumači samo jedan glumac. To je vješta konstrukcija simboličke slike vlasti, koja nam pokazuje, da je vlast, bez obzira na ime i titulu, uvijek ista: bezglava, sa dvije glave, gnjecava, prevrtljiva i osvetoljubljiva, strašna kada se sveti i još strašnija kada prašta. Njegov Zmaj od Bosne predstavlja modernu dramu isprepletenu od različitih stilskih elementa, tako da $\mathrm{u}$ njoj možemo naći i neoekspresionističke stilske zahvate iz fakcije u fikciju, ali i dosta elemenata farse, pa i grotesknih elemenata koji su tipični za drame apsurda.

Ono što najviše ovaj dramski tekst razlikuje od svih ostalih dramskih tekstova koji su posvećeni Huseinu-kapetanu Gradaščeviću je svakako doživljaj samoga glavnoga junaka, jer to više nije romantični doživljaj i zanos kojem je jedini zadatak da idealizira i veliča Huseina kao nacionalnog heroja, nego je to više drama dekonstriuranja i demitomanizacije jednog nacionalnog heroja, koji to odista jeste bio, ali je pored toga bio i samo čovjek sa svim svojim vrlinama, manama i prelomima. Upravo zbog te činjenice, ovu dramu možemo determinirati kao dramski tekst koji više nije drama povijesti, nego on prerasta u povijesnu dramu. Ovakva dramska determinacija se može objasniti upravo tom činjenicom da ona tematizira sve ono što je Gradaščević preživio, a ne ono zbog čega je Gradaščević to preživio i samim tim pristupom se u startu odbija klasična idealizacija historijskog dramskog lika u sklopu nacionalromantizma.

O tome profesorica Muzaferija kaže: "I baš u tom sagledavanju načina podnošenja uspona i pada, u upozorenju na njegovu brzu slavu $i$ još brže suočenje sa patnjom velikih, sadržano je univerzalno značenje Ibrišimovićevog dramskog junaka. Njegova vertikala spoznaje samoga sebe odvija se na fonu stvarnih historijskih zbivanja, koja metodom analitičke drame ulaze u strukturu, kap po kap, čineći njen "prednji plan", dok se u "pozadini" uspostavlja parabola iz prošlosti za sadašnjost i postaje svevremena. ${ }^{22}$

Dakle, upravo taj metod da je u prvom dramskom planu istaknut junak koji spoznaje sama sebe i u toj spoznaji biva poražen je onaj

${ }^{2}$ Muzaferija, Gordana: Činiti za teatar, Centar za kulturu i obrazovanje, Tešanj, 2004., str. 118. 
konstruktivni metod koji je Ibrišimovića spasio od opasne, ali i umilne zamke da idealizira svoga dramskog junaka, pa tek u drugom dramskom planu razrađuje historijski okvir koji determinira njegovog junaka. Ovakva paralelizacija općeljudskog psihološkog sazrijevanja, koje podrazumijeva uspone i padove $\mathrm{u}$ determinaciji sa konkretnim historijskim vremenom, čini to vrijeme sveobuhvatnim i univerzalnim. Husein munjevitom brzinom prelazi trnoviti put, od kapetana pa sve do vezira, ali upravo ga taj njegov uspjeh na kraju i košta glave, jer on kao pobunjenik protiv sultana mora da bude nečasno uklonjen, bez obzira na motive koji ga pokreću, pa bio to i vlastiti patriotizam. Šahinović i Muradbegović su svoje drame završili na Zlom stupu, izgubljenom bitkom, a za razliku od njih, Ibrišimović radnju nastavlja dalje, on pomno prati Huseinov tragični put u samu smrt, pa prenosi dramsku radnju u: Osijek, Zemun, Beograd i Carigrad. To su upravo najtragičnije slike Huseinovog života, jer svi počinju da ga odbacuju i da "peru ruke" od bune, te ga kao žrtveno jagnje guraju prema Carigradu/sultanu/smrti. Ovakav dramski zaokret je tipičan za dramu vlasti još od antike pa do danas. Dramski junak kasnije i sam okrvavljuje ruke, postajući tako žigosan kao neodvojivi dio vlasti i dio politike. U svom trnovitom putu ka vrhu, Husein se i sam na momente pretvara u tipičnog vlastodršca i naređuje smrtnu kaznu za sve one koji neće da mu se pokore... postaje isti kao oni protiv kojih se i sam bori, i biva užasnut sviješću o svojim krvavim rukama. Ova strašna spoznaja je simbolično prezentirana kada Husein preko krvave halje navlači vezirsko ruho i u tom trenutku se približava nadohvat smrti, te postaje gnjecav kao ilovača, baš kao i omražena i trula utvara Dželaludin-paše.

"ĐULA: Paša moj! Huseine! Sav si krvav!

HUSEIN: Kaznio sam Selmanovića iz Teslidže zato što je obrekao sveti boj kod Kačanika!

ĐULA: Skini tu halju sa sebe, eto te k'o kakva utvara! Obuci ovo ruho vezirsko što si dao da ti ga skroji tvoj terizbaša nad terazijama! Skini to sa sebe! Nisi derviš! 
HUSEIN: (Husein preko one krvave halje oblači bogato vezirsko ruho pri tome mu pomaže Fidahić) ${ }^{\prime{ }^{3}}$

Husein tako i sam postaje žrtva nepobjedive vlasti i žeđi za vlašću koja ga izjeda kao individualca slobodne misli i tjera ga da i sam okrvavi ruke. Cijela dramska radnja je raščerečena između pobune i slijepe vjere u pobjedu, te kazne za neposluh i degeneracije pod uticajem moći i vlasti, tako da radnja drame protiče na razini svijesti.

Husein predstavlja klasičnog tragičnog junaka koji se kao individualac otvoreno sukobljava sa izaslanicima centrale moći (vlasti) i zbog toga biva potpuno uništen. Taj pokušaj da se općoj volji naredi svoja pojedinačna, je ono što još od antike pokreće tragične dramske junake. Đula, žena Huseinova, ona je kao i ledi Magbet po pitanju muževog slavoljublja i častoljublja, ali gaji i vlastite planove $i$ ambicije, te želi da ga vidi na samom vrhu vlasti. Međutim, u trenucima pada i poraza, kada je došlo do sudbonosnog pitanja života i smrti, ona pokazuje da je iza svega toga, samo obična žena koja ga silno voli.

"Uvijek sam žarko željela da budeš nešto više od drugih ljudi, a sad bih tako željela da si niko i ništa... Sultan ti nudi oproštaj, čak đeneralska odličja, nemoj se gorditi, što ćeš mi mrtav, mrtav mi ne trebaš..." ${ }^{\text {t }}$

U zadnjim scenama Ibrišimović uvodi nekoliko novih i izuzetno zanimljivih likova koji na neki način oživljavaju dramu i koji su iskorišteni da tragičnom Huseinovom padu i historijskom i ličnom daju notu filozofsko-poetske aure. Ovaj dramski tekst je prenapregnut sa akcijom i u momentima se moć začas okreće u potpunu bespomoćnost, ali se ona ujedno i dekonstruira kroz vječno definiranje vlasti i moći između egzistencijalne i moralne sfere postojanja. U onim momentima kada je Husein već okušao kako je to imati vlasti, ali i kako je to biti potpuno bespomoćan, on postavlja pravo filozofsko pitanje razapeto između iskonih potreba svakoga čovjeka, i onih

\footnotetext{
${ }^{3}$ Nedžad Ibrišimović: Zmaj od Bosne, Drame, "Veselin Masleša", Sarajevo, 1988, Str. 37.-38.

${ }^{4}$ Nedžad Ibrišimović: Zmaj od Bosne, Drame, "Veselin Masleša", Sarajevo, 1988, str. 56.
} 
egzistencijalnih i onih moralnih, kada se zagleda u svoju skicu koju je napravila Đulija fon Čerge.

"HUSEIN: (Uzme crtež) To sam ja! Sumnjao sam, strahovao, sad vidim! Samo sjena! Obris! Samo blijeda sjena negdašnjeg Gradaščevića! Da puhnem bih se oduvao... Ja sam utvara! ... Utvara! ... Mene gotovo nema...!

ĐULIJA: Odmah mi vratite moj skicen-blok! Odmah! I ne duvajte u to!

HUSEIN: Rukom da mahnem bih te istro, Husein-kapetane!..." ${ }^{5}$

Ova historijska drama funkcionira kao drama identiteta, ali je Ibrišimović uspio postići maksimalnu koncentraciju na univerzalno, obuhvativši tako opću ljudsku dramu u kojoj su ljudi izgubljeni i uplašeni samih sebe, jer nisu ništa drugo nego svoja vlastita sjena. Najpotresnija dramska scena je upravo ona u kojoj je Husein najviše svoj i najviše nostalgični pjesnik, to je onaj trenutak kada on ljubomorno čuva od sultana svoje utiske sa putovanja od Beograda do Carigrada, kao da su ti utisci najveća državna tajna, jer on je u tom trenutku smrtno bolestan i već svjestan da je spoznao misteriju ljudskog postojanja, koja mu se otkriva u zimskim pejzažima. On spoznaje surovu i hladnu odvojenost svijeta od čovjeka, te se miri sa činjenicom da je čovjek uvijek stranac u vlastitom svijetu. Ono što je najviše bolno za Huseina je prihvatanje spoznaje da je Bosna zemlja koju je zauvijek napustio i da ona od tog trena za njega može postojati samo u emanaciji njegovih sjećanja, te upravo zato ljubomorno čuva svoje utiske sa putovanja kroz zimske pejzaže, jer je to jedino od Bosne što mu sultan ne može oduzeti.

"SULTAN: Kako je bilo na putu?

HUSEIN: Dobro...

SULTAN: Pravo reci...

HUSEIN: Pravo...?

SULTAN: Jah.

HUSEIN: Žao mi reć'...

\footnotetext{
5 Ibrišimović Nedžad, Zmaj od Bosne, Drame, "Veselin Masleša", Sarajevo, 1988, str. 56.
} 


\section{SULTAN: Šta?}

HUSEIN: Snijeg, snijeg, snijeg sam gledao kako pada... Na drugo se nisam obazirao.

SULTAN: I to ti je bilo žao reći...?"16

Sniježni pejzaž je za Huseina njegova Bosna koju on ljubomorno čuva samo za sebe. Upravo su kroz elemente Huseinovog nostalgičnog zanosa i vezani rijetki lirski odlomci ovog dramskog teksta, iako je cijela drama u oštrom ekspresionističkom tonu. Posebno je poetski imaginativna lirska metafora Bosne kao oslonca za njegovu dušu, jer on sumnja u sve, osim u Bosnu. Sama Bosna je jedna pjesma, jer on kaže da bi dao sve kada bi Bosna bila jedna kasida ili bar jedan gazel.

"HUSEIN: (Razotkriva je) I ovo me boli!... I ovo... na tebi... Uh, kako mene sve ovo boli! Nisam znao da bih dao sve što imam samo kad bi Bosna bila jedna kasida ili makar jedan gazel!

ĐULA: Cijela Bosna?

HUSEIN: Cijela Bosna i Hercegovina!"'7

Ovo je jedan od rijetkih primjera lirizima u ovom dramskom tekstu, a svi poetski elementi su kroz cijeli dramski tekst vezani za Bosnu. Međutim, cijela drama obiluje elementima ironijskog i grotesknog, što je posebno izraženo u zadnjoj sceni, jer Gradaščević svjesno gubi bitku sa ovim svijetom, iako on ostaje dosljedan sebi, on razrješava svoje odnose sa ljudima i samim sobom, ali on postaje svjestan da ni na onom svijetu neće naći smiraj, jer i nad njegovim grobom lebde muka i dušmani, čime se ironizira i nada u smiraj na drugom svijetu koji ne predstavlja ništa drugo, do novi beskonačan okvir za neko novo stradanje i neku novu muku i tako u nedogled. Tako Husein ne nalazi smiraj ni u grobu, jer strepi za budućnost svoga sina Muhameda i upravo ovakav dramski rasplet najviše podsjeća na teatar apsurda i njegovu apokaliptičnu viziju svijeta.

"HUSEIN: Nisam toliko griješio! A ako jesam Allah će mi suditi! Ja više ništa ne mogu, ja umirem... Jedino mi reci: kad odem

\footnotetext{
${ }^{6}$ Ibrišimović Nedžad, Zmaj od Bosne, Drame, "Veselin Masleša", Sarajevo, 1988, str. 53.-54.

${ }^{7}$ Ibid., str. 38.
} 
hoće li koja tegoba lebdjeti nad mojim grobom? Hoće li, kada umrem, moju muku zrak razrijediti... hoće li se dušmani na nju laktovima oslanjati, ne daj Bože, moga Muhameda pritiskati...." ${ }^{\prime 8}$

Ovakav dramski završetak najbolje potvrđuje Ibrišimovićev zaokret iz historijskih fakata u bogato univerzalno značenje, on se dakle kreće od Huseina kao konkretne historijske ličnosti koja se bori sa problematikom svoga vremena, do Huseina kao čovjeka koji shvata besmisao ljudske egzistencije i na taj način nam prezentuje književnoumjetničku istinu, koja duboko zadire u unutarnje nezadovoljstvo savremenog i svevremenog čovjeka. Ovakva grandiozna historijska ličnost i njegova borba za nezavisnost Bosne i Hercegovine će postati jedna od najinspirativnijih tema na kojima su svoja književna djela gradili mnogi bošnjački autori, ali i historičari, čija djela o ovom bošnjačkom velikanu imaju i svojevrsnu dozu literarnosti.

\section{Nijaz Alispahić, Zmaj od Bosne ili klasična historijska građanska drama sa izraženim ideološkim supstratom}

Sam naslov drame Zmaj od Bosne Nijaza Alispahića ima inkoativnu, referencijalnu i metatekstualnu funkciju, te uvodi recipijente drame u nadređenu perspektivu u odnosu na aktere dramskog prikazanja i daje određenu dozu dramske ironije koja proizlazi iz predznanja o radnji koja se scenski izvodi. Pored naslova, kao dio pomoćnog dramskog teksta javljaju se i podnaslovi koji su određeni za svaku scenu, a koji također imaju značajnu ulogu pri cjelokupnoj recepciji dramske prezentacije. Ovakva segmentacija drame na pojedinačne dijelove (scene, međuprizore) od kojih svaki može da funkcionira sam za sebe, i predstavlja "komad u komadu", je također svojevrsno epiziranje dramskog teksta, što djeluje na uključivanje recipijenata u samu unutrašnjost drame.

Drama Zmaj od Bosne ima klasičnu formu građanske historijske drame koja je utemeljena na ideološkom supstratu koji je u ovoj drami jako izražen, i on je obilježen kao i većina drama ovakvog tipa tezom o vječitoj bosanskohercegovačkoj međunacionalnoj podijeljenosti

\footnotetext{
${ }^{8}$ Ibrišimović, Nedžad: Zmaj od Bosne, Drame, "Veselin Masleša", Sarajevo, 1988, str. 57 
koja uzrokuje nezaustavljive političke turbulencije, što uvijek olakšava nekim tamo tuđincima da manipulišu bosanskom državom. Alispahić se dosljedno drži historijskih fakata i ustvari na određen način i zanemaruje prave uzroke Gradaščevićeve pobune, koji će se tek na kraju drame preciznije definirati. Ovdje je svakako Gradaščević prikazan pomalo romantično, ali i pomalo kao izgubljen čovjek koji je politički nesposoban i koji sa sobom u propast vuče još masu ljudi. Tako on podsjeća na epske junake iz čuvene krajiške epike, te više pravde vidi u svojoj silovitosti i u maču, nego u knjizi i sudskom kantaru. Junake po sistemu: "Ne dam nama, pa nek' ide glava", ali upravo su takvi junaci i bili omiljeni u našem narodu, više od onih koji se oslanjaju na puku inteligenciju i odišu mirnoćom. Takvi junaci su oslikani ironijom i to je ono najvrijednije u ovoj drami, realizirano kroz ironični dijalog dva pehlivana koji više nabacuju komentare o jadu i bijedi Bosne, nego o tragičnoj sudbini glavnog junaka. Iskorišten je i sukob na intimnom planu između Huseina i njegovog starijeg brata Osmana, koji je vjerni poslušnik osmanlijske uprave i koji ga pokušava urazumiti da se ne buni protiv sile i da ne vuče u propast ljude oko sebe.

"Osman-paša: Moj Huseine! Da sve što po Bosni na dvije noge hoda pretvoriš u ratnike, bilo bi šaka jada naspram sultanovog dičnog nizama. Kud si se zaputio s ovom bosanskom golotinjom, brate Huseine! Hoćeš $i$ njoj $i$ sebi da navučeš samo bijedu na vrat. To hoćeš! Je li to tvoje stajanje na bedemima Bosne?

Gradaščević: Kakva je takva je, moja je! Bosna diše mojim dahom. Ja bosanskim. Na Kosovu sam se uvjerio u snagu sultanovih ratnika. Ne bojim se tog tvog dičnog nizama! I počesto se razgalim onom pjesmom: "Ne bojim se nikog do boga, malo cara nimalo vezira, a sultana ko dorata svoga..."

U ovoj replici se vidi koliko je Gradaščević prkosan i samouvjeren u svoju snagu i pobjedu, a koliko je malo okarakterisan kao vičan diplomata koji bi svojom mudrošću pokušao da isposluje neke ustupke kod sultana. Drama je strukturirana na sličan način kao i Alispahićeva Hasanaginica, pa i ovdje imamo dvojicu pehlivana Šahina i Tamburiju, koji povremeno na ironičan način izvještavaju

9 Alispahić, Nijaz, Zmaj od Bosne, Biblioteka "Prvaizvođenja", Sarajevo, 1989, str. 17. 
recipijente drame o zapletu dramske radnje, ali je ovdje njihova ironija jače naglašena nego kod Hasanaginice.

"Šahin i Tamburija:

Nema takve jadnice

Nema takve gladnice

Nema takve klanice

I nema takve jaranice

Kao što je zemlja Bosna

Kao što je zemlja Bosna." ${ }^{\prime 10}$

Također je njihov dramski tekst markiran, jer oni više govore $u$ stihovima nego u proznom tekstu, za razliku od proznog teksta nultog stepena u ostatku drame, pa je ironija još više naglašena. Ponekad njihovo kazivanje u stihovima podsjeća i na narodni epski deseterac iz junačkih pjesama, što je posebno izraženo kod njihove prezentacije sukoba na Zlom Stupu. Ovo nam daje posebnu notu arhaičnosti, a ujedno i ironizira mitski pojam junaštva koji je uvijek prisutan $u$ takvoj vrsti epike.

"Tamburija:

A da vidiš Tuzlu-kapetana

U Olovu čibuk ispružio

Srče kahvu ne haje za bitku

Šahin: A da vidiš Ibre kafedžije

Usro pritku, napustio bitku. "11

Preko pehlivana Alispahić uvodi i igru sa scenom teatra u teatru u kojoj ironizira vječiti položaj Bosne koja je rastrgana između svjetskih sila i koja nikad nije samo svoja, te da je svaki otpor tome uzaludan.

"Šahin: Ja sam sultan

\footnotetext{
${ }^{10}$ Alispahić, Nijaz, Zmaj od Bosne, Biblioteka "Prvaizvođenja", Sarajevo, 1989, str. 42.

11 ibid. str. 57.-58.
} 
Tamburija: A ja car

Šahin: Tu je Bosna moja stvar

Tamburija: Tu je Bosna moja stvar

Šahin: Moja.

Tamburija: Moja.

Šahin: Moja.

Tamburija: Moja. (Svađa) $)^{\prime 12}$

Ovakva, gotovo infantilna igra (pozorište u pozorištu) u ovoj drami reprezentuje veliki sloj ironije na savršeno jednostavan način, te se može zaključiti da najveći potencijal ovog dramskog teksta leži upravo u pehlivanskim komentarima. Sam kraj drame je otvoren i u epilogu imamo opširnu didaskaliju koja zahtijeva roj muzike, glasova, brzog ritma, i plesačica

"...Gradaščević je u bezizlaznom zatvorenom krugu, koji postaje sve manji, uži. Zatim se sve stiša, Gradaščević je "samac usred svemira". Na koju god stranu da pođe dočekuju ga iskežene glave Mula Halima, Rizvanbegovića, Osman-paše, Sejjfudin eff., Melećhanuma... I glasan smijeh koji odjekuje svemirom. Glave se cerekaju, govore.

Nakon apsurdne slike igre mrtvih i odsječenih glava dolazi do skamenjivanja scene, tipičnog postupka u modernom pozorištu, ali onda na scenu izlaze Pehlivani i recitiraju pjesmu "Bosna" Maka Dizdara. Ovdje imamo specifičnu intertekstualnost, i kraj je jako sličan kao kod Hasanaginice gdje se drama također završava sa recitiranjem stihova Maka Dizdara - Smrt nije kraj.

Ovakvo intertekstualno uplitanje poezije u dramski tekst ima višeznačnu ulogu i vodi nas ka recepciji univerzalnih vrijednosti, što je Alispahić iskoristio u oba slučaja. Recitiranje pjesme Bosna na samom kraju drame, nas dovodi do šoka, do shvatanja da su historijski likovi i zbivanja iskorišteni samo kao medij za reprezentovanje poruke specifičnog bosanskog bivstvovanja, koje je oduvijek opterećeno sa

\footnotetext{
12 ibid. str. 65.

13 Alispahić, Nijaz: Zmaj od Bosne, Biblioteka "Prvaizvođenja", Sarajevo, 1989, str. 84.
} 
raznim konfesionalnim rascijepljenostima i kao takvo lak plijen tuđincima, ali bez obzira na to sve, njegova srž je uvijek u prkosu i u buntovnosti.

Po svom osnovnom tonu, drama se može odrediti kao historijska, s čim nužno postaje i politička, ali ona ujedno može da se odredi i kao egzistencijalistička drama. Osnovni dramski problem je građen na vječitoj demistifikaciji vlasti i problem egzistencije $u$ suodnosu sa jačim i moćnijim. Samo predznanje recipijenata i horizont njihovog iščekivanja je proizveo ironiju koju pojačavaju pehlivani, pa je vidljiva brehtovska distanca. Međutim, drama nije svedena na puku ironiju, nego se u mračne ironične scene unose $\mathrm{i}$ humor, narodne doskočice, lascivnost, pa je s toga jako dinamična i recipijentima prijemčiva. Dramski tekst je sastavljen od četrnaest slika sa epilogom i u suštini odano počiva na historijskoj građi osim na samom kraju drame gdje se obrađuje smrt Husein-bega Gradaščevića.

\section{Fuad Tabak, Husein-beg Gradaščević ili individualaca u sukobu sa svijetom koji ga okružuje}

Dramski tekst Husein-kapetan beg Gradaščević Fuada Tabaka prvo je nastao kao monodrama, da bi ga zatim autor razradio $\mathrm{u}$ tročinku, prepunu antagonističkih sukoba između mnogobrojnih likova koje uvodi iz područja porodičnog i političkog života toga vremena. Radnja drame se ne završava porazom na Zlom stupu, nego se ona prenosi dalje sve do Stambola i Gradaščevićeve smrti. Ovim prostornim prebacivanjem je ostvareno i prebacivanje sa političke drame na dramu intimnog plana. Gradaščevićev politički poraz uvjetovan je sa njegovim ekscentričnim dostojanstvom, što je posebno izraženo u trećem činu, gdje kroz retrospektivne događaje imamo prikaz psiholoških sukoba unutar Zmaja od Bosne. Sam treći čin predstavlja specifičnu dramsku završnicu i cjelokupan se može definirati kao pozorište u pozorištu. Ovaj treći retrospektivni čin je po ocjenama književne kritike ključ za razumijevanje prave vrijednosti ove drame, jer se u njemu sukobljavaju Huseinova intimna i javna tragedija. Prikazan je Huseinov put od moćnog čovjeka, lidera i vođe, do slomljenog čovjeka, stranca, bez igdje ikog svoga, zatvorenika i prezrenog čovjeka. U njemu se odvija psihološki lom u kojem on spoznaje samoga sebe i svoju bezuspješnu borbu, tada on shvata da je 
jedini izlaz iz proklete ljudske sudbine u vječitoj tišini, šutnji, smrti. Tabak je Zmaja od Bosne prikazao kao tipičnog tragičnog historijskog junaka koji postaje žrtva vlastitog sukoba protiv cijelog svijeta (sultana, vlasti, porodice), ali je uspio izbjeći klišeiziranje romantičarske patriotske poruke, već je glavni dramski akcent stavljen na čovjeka kao individualaca u sukobu sa svijetom koji ga okružuje. Kraj drame je otvoren, dramska radnja završava sa Huseinovim monologom koji ga vodi u smrt, ali ujedno navodi i dramske recipijente da analiziraju njegovo duboko razmišljanje o ništavnosti čovjekovog života i snažnoj političkoj mašineriji, ali i o nostalgiji i ljudskom ponosu.

"Husein: U Bosni je sad proljeće. Miriše behar i šume su zelene. Džennet na Zemlji!...Zašto li sam bio?...Ima neki razlog!...Moja riječ, pokret moje ruke, brisali su nit što dijeli život od smrti!...Imao sam sve... a ostao sam ...s nešto slika i riječi...i nešto ljubavi...

(Husein se hvata rukom za srce i spušta se na koljena. Podiže ruke na molitvu. Glava mu nemoćno klone..) "14

\section{Zaključak}

Bogati period bosanskohercegovačke historije koji obuhvata vrijeme osmanlijske vladavine uspješno je iskorišten u raznim književnim žanrovima, ali u dramskim tekstovima postaje omiljen, jer nudi na razmatranje dosta veliki broj historijskih ličnosti preko kojih se najčešće prikazuje borba za samostalnost i nezavisnost Bosne i Hercegovine i otpor okupatoru ma sa koje on strane dolazio. Nije ni čudo da je zbog svega toga Husein-beg Gradaščević jedan od najomiljenijih junaka koji impresionira dramske stvaraoce i koji "seciraju" njegovu političku i duhovnu borbu u Pokretu za autonomiju Bosne. No, s obzirom da je osnovna podloga svake historijske drame $\mathrm{u}$ modernom smislu u političkom pozorištu, ono za što se osmanlijski period iskorištava $\mathrm{u}$ tkanju dramskih tekstova jeste njegova metamorfozična narav, koja je omogućavala dramskim autorima da razmatraju probleme ideoloških pritisaka na vrijeme sadašnje. Svaka historijska drama ima uvijek isti cilj, a to je da se iskoristi ona

14 Tabak, Fuad: Husein-beg kapetan Gradaščević, Drame, "Ljiljan", Sarajevo, 2002. str. 81. 
mogućnost igre koju pozorište pruža, da se putem prošlosti, naruga sadašnjosti u smislu dekonstruiranja gorućih problema, ili da se u paralelnom prezentiranju sličnosti između vremena prošlog i vremena sadašnjega progovori o onom univerzalnom. Taj svojevrsni utilitarni cilj je onaj zajednički konstruktivni element koji povezuje sve historijske dramske tekstove, bez obzira na međusobne diferencijalne specifikume. Očigledno je da ovakva vrsta dramskih tekstova nastaje isključivo kao supstitucija političkog teatra, koji se na našim područjima, zbog stroge jednopartijske ideologije, nikada nije razvila u pravom smislu te riječi, ali je zato putem historijskih dramskih tekstova dugo vremena vršena ironizacija društvenih problema naših područja, ali i problema koje muče čovjeka u smislu njegove egzistencije u zajednici kroz cijelu kulturalnu historiju čovječanstva. Tako historija kao tematski izazov postaje nepresušivi izvor inspiracije dramskim stvaraocima, ali i umjetnicima općenito.

\section{Literatura:}

1. Aličić, Ahmed: Pokret za autonomiju Bosne od 1831. do 1832. godine, Orijentalni institut u Sarajevu, Sarajevo, 1996.

2. Alispahić, Nijaz: Zmaj od Bosne, Biblioteka "Prvaizvođenja", Sarajevo, 1989.

3. Ibrišimović, Nedžad: Zmaj od Bosne, Drame, "Veselin Masleša", Sarajevo, 1988.

4. Katnić-Bakaršić, Marina: Stilistika dramskog diskursa, Vrijeme, Zenica, 2003.

5. Kraj utopije i pozorišta. Kritike i eseji (1985-2000), Otkrovenje, Beograd Sterijino pozorje, Novi Sad 2000.

6. Kreševljaković, Hamdija: Kapetanije u BiH, Svjetlost, Sarajevo 1980.

7. Lešić, Josip: Dramska književnost II, Institut za književnost/Svjetlost, Sarajevo, 1991.

8. Lešić, Josip: Savremena drama i pozorište u Bosni i Hercegovini, Sterijino pozorje, Novi Sad, 1984.

9. Lešić, Josip: Savremena dramska književnost u Bosni i Hercegovini (tema i struktura), U: Drame, Savremena književnost naroda i narodnosti BiH u 50 knjiga, Svjetlost, Sarajevo, 1985.

10. Lešić, Josip: Vrijeme prošlo - vrijeme sadašnje, Scena, 1970, br. 1-2.

11. Lešić, Zdenko: Nova čitanja. Poststrukturalistička čitanka, Buybook, Sarajevo, 2003. 
12. Lešić, Zdenko: Teorija drame kroz stoljeća, Svjetlost, Sarajevo, 1977.

13. Lešić, Zdenko: Kapidžić-Osmanagić, Hanifa, Katnić-Bakaršić, Marina i Kulenović, Tvrtko: Zbornik radova grupe autora/autorica, Suvremena tumačenja književnosti, Sarajevo Publishing, Sarajevo, 2007.

14. Melchinger, Siegfried: Povijest političkog kazališta, Grafički zavod Hrvatske, Zagreb, 1989.

15. Miočinović Mirjana: Moderna teorija drame, Nolit, Beograd, 1981.

16. Muzaferija, Gordana, Rizvanbegović, Fahrudin, Vujanović Vojislav: Antologija bošnjačke drame XX vijeka, Alef, Sarajevo, 2000.

17. Muzaferija, Gordana: Bosanskohercegovačka drama ili Dijalog s vremenom. U: Činiti za teatar, Centar za kulturu i obrazovanje, Tešanj, 2004.

18. Muzaferija, Gordana: Bošnjačka književnost u književnoj kritici, Novija književnost - Drama, Alef, Sarajevo, 1998.

19. Muzaferija, Gordana: Između historije i savremenosti (bosanskohercegovačka drama 1967-1977), U: Činiti za teatar, Centar za kulturu i obrazovanje, Tešanj, 2004.

20. Pavis, Patrice: Pojmovnik teatra, Izdanja antibarbarus, Zagreb, 2004.

21. Pfister, Manfred: Drama. Teorija i analiza, Hrvatski centar ITI, Zagreb, 1998.

22. Selenić, Slobodan: Dramski pravci XX veka, Umetnička akademija u Beogradu, Beograd, 1971.

23. Tabak, Fuad: Husein-beg kapetan Gradaščević, Drame, "Ljiljan", Sarajevo, 2002. 
Amra Memic, MA

THE GREAT BOSNIAKS: HUSSEIN-BEY CAPTAIN

GRADASCEVIC (THE DRAGON OF BOSNIA) THROUGH THE

HISTORICAL KALEIDOSCOPE OF THE DRAMATIC

CREATIVITY OF NEDZAD IBRISIMOVIC, NIJAZ ALISPAHIC

AND FUAD TABAK

\section{SUMMARY}

Aims and objectives of this work are manifested in the desire to contribute to the assertion that an embryo of the historical dramaturgy should be sought in the social need for political theater. Thus the past is used through the messages of universal value in order to demystife contemporary issues. So, the dramas which have their inspirational starting point in the past, use the past only as a fertile ground for the actualization of some contemporary issues, and thus speak of the universal. Since Bosnian drama was not sufficiently researched, it is not surprising how little has been written on Bosnian historical drama, which was at one time the most dominant orientation of the drama writers. In the historical plays, the most important are those who are inspired by the great figures of Bosniaks such as: Gradascevic Hussein-Bey, Mehmed-Pasha Sokolovic, Mullah Mustafa Baseskija, Mufti Karabeg, Abdulvehab Ilhamija, Zepcevi, Gerzelez Ali and many others.

Keywords: historical drama texts, history, history of mentalities, political theater, The Movement for Bosnian Autonomy, a symbiosis of past and present, demystification, Hussein-Bey Gradascevic, The Dragon of Bosnia, Nedzad Ibrisimovic, Nijaz Alispahic, Fuad Tabak 


\section{م.عمرة ميميتش}

كبار البشـانقة: حسين بيك كابيتان غراداشتشيفيتش (التنين من البوسنة) من خلال

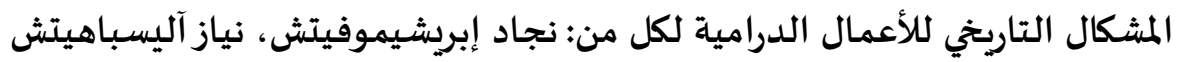
وفؤاد تاباك

\section{خلاصة البحث}

أهداف ومهام هذا البحث تتمثل في الرغبة أن ندعم الفرضية أن جنين الدراما التاريخية ينبغي أن نبحث عنه في الحاجة الاجتماعية إلى المسرح السياسي الذي على الى الى

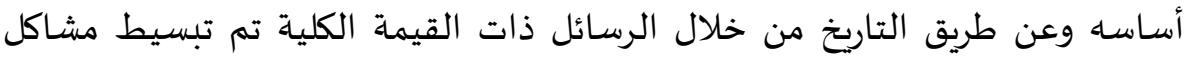

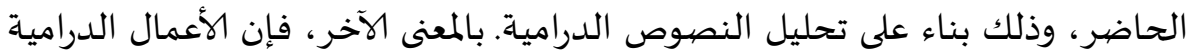

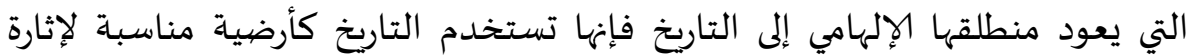
المشاكل المعاصرة وبالتالي تتكلم عن الكلي. بما أن الدراما البوسنوية لم تبحث بشكل كافٍ فلا غرابة في قلة ما كتب عن عن

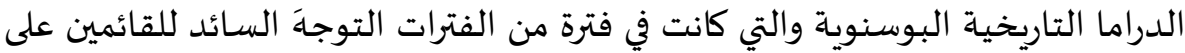

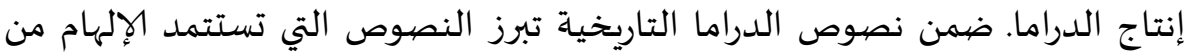

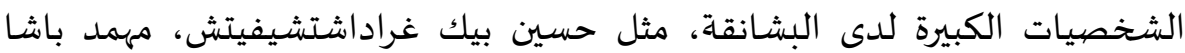
سوكولوفيتش، ملا مصطفى باشسكييا، مفتي كارابيك، عبد الوهاب إلهامي جبتشافي، علي غرغليزوغيرهم كثير.

الكلمات الرئيسة: نصيوص الدراما التاريخية، التاريخ، تاريخ العقلية، المسرح

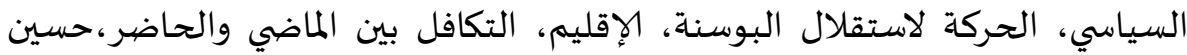

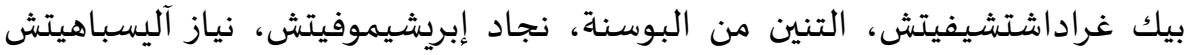
وفؤاد تاباك 